\title{
Three Arguments for Underspecified Representations
}

\begin{abstract}
In classic generative phonology (The Sound Pattern of English, Lexical Phonology) underlying representations and associated rules account for generalizations of two types: alternation-based generalizations and distribution-based generalizations. This article addresses the issue of how distribution-based generalizations are handled in Standard Optimality Theory and in Derivational Optimality Theory. The former uses the principle of the Richness of the Base, the latter relies on underspecification. It is argued that the Richness of the Base and the associated principle of Lexicon Optimization are unable to provide an adequate analysis of three types of generalizations: Nasal Assimilation in English, Vowel Retraction in the process of assimilating borrowings into Polish, and a presonorant voicing process called Cracow Voicing.
\end{abstract}

\section{Keywords}

phonology, Polish phonology, Derivational Optimality Theory, underlying representations

\begin{abstract}
W klasycznej teorii fonologii generatywnej reprezentowanej przez Sound Pattern of English reprezentacje głębokie i związane $\mathrm{z}$ nimi reguły fonologiczne odzwierciedlają dwa rodzaje generalizacji: generalizacje oparte na alternacjach i generalizacje oparte na dystrybucji dźwięków. Niniejszy artykuł omawia problem reprezentacji dystrybucyjnych i sposobu ich opisu z punktu widzenia standardowej teorii optymalności i derywacyjnej teorii optymalności. Teoria standardowa wprowadza zasadę wzbogaconej reprezentacji głębokiej (Richness of the Base), natomiast teoria derywacyjna - zupełnie odwrotnie - postuluje reprezentacje pozbawione wszelkiej redundancji (underspecified representations). Niniejszy artykuł dowodzi, że teoria standardowa nie jest w stanie opisać trzech rodzajów generalizacji: reguły asymilacji nosowej w języku angielskim, reguły cofania samogłoskowego w języku polskim oraz reguły tzw. udźwięczniania krakowskiego.
\end{abstract}

\section{Słowa kluczowe}

fonologia, fonologia polska, derywacyjna teoria optymalności, reprezentacje głębokie w fonologii 


\section{Underspecification in underlying representation: Nasal Assimilation}

Research in generative phonology has been guided by Postal's (1968) Naturalness Condition stating that underlying representations may diverge from surface representations to the extent motivated by the need to capture phonological generalizations. These are of two types: alternation-based generalizations and distribution-based generalizations. The former are illustrated by the negative prefix in-found in English adjectives.

(1) English prefix in-

$$
\begin{aligned}
& \text { possible }-i m+\text { possible [Imp] } \\
& \text { tolerant }-i n+\text { tolerant [Int] } \\
& \text { complete }-i n+\text { complete [Ink] } \\
& \text { accurate }-i n+a \text { ccurate [Inæ] }
\end{aligned}
$$

An analysis of these data is uncontroversial in all frameworks of generative phonology: the underlying representation of the prefix is $/ \mathrm{m} /$, with $/ \mathrm{n} /$ because [n] occurs before a vowel in inaccurate. The surface alternations between [m], [n] and [n] are derived by Nasal Assimilation, a rule or a constraint, depending on the framework. Assuming Optimality Theory (Prince and Smolensky 2004; McCarthy and Prince 1995), Nasal Assimilation is stated as an agreement constraint.

(2) Nasal Assimilation (NA)

A nasal and a stop ${ }^{1}$ must agree in PlaCE.

Executing the demand of NA by, for example, changing $/ \mathrm{n} /$ to $[\mathrm{m}]$ in imposible, $/ \mathrm{In}+\mathrm{p} / \rightarrow[\mathrm{Imp}]$ violates IDENT-PL.

(3) IDENT-PL

PLACE on the input segment must be preserved on a correspondent of that segment in the output. ${ }^{2}$

Unlike classic rule-based frameworks, Optimality Theory (OT, henceforth) does not write directionality into the statement of NA, the consequence being that NA is satisfied by both [Imp] and [Int] as outputs from the input /Inp/. Directionality is regulated by a positional faithfulness constraint (Beckman 1997; Casali 1997).

\footnotetext{
${ }^{1}$ The term 'stop' is used here to refer to plosives and affricates.

2 As argued in Pater (1999), Struijke (2000) and Rubach (2003a), IDENT constraints are unidirectional I(nput) $\rightarrow \mathrm{O}$ (utput), mandating preservation of the input properties, and O(utput) $\rightarrow \mathrm{I}$ (nput), penalizing candidates in which the feature not present in the input occurs in the output (addition of a feature).
} 
(4) IdENT-PL $)_{\text {Onset }}$

PlACE on the input segment must be preserved on an output correspondent of that segment in the onset.

The evaluation of impossible is now as follows. We look only at the relevant portion of the word. Dots mark syllable boundaries, the icon denotes the winner.

(5) $/ \mathrm{In}+\mathrm{pa} / \rightarrow[\mathrm{Impa}]$

\begin{tabular}{|c|c|c|c|c|}
\hline & & NA & IDENT-PL) ${ }_{\text {Onset }}$ & IDENT-PL \\
\hline (a) & In.pa & $* !$ & & \\
\hline (b) & In.ta & & $* !$ & * \\
\hline (c) & Im.pa & & & * \\
\hline
\end{tabular}

Candidates (5b) and (5c) equally satisfy NA because the nasal and the stop are homorganic. The tie between (5b) and (5c) is broken by IDENT-PL) ${ }_{\text {Onset }}$ that mandates the preservation of PLACE on the segment that finds itself in the onset in the output candidate. This segment is the stop since the syllabification is [Im.pa]. The [m] is in the coda because the putative [I.mpa] would violate sonority relations in the onset (Jespersen 1904; Selkirk 1982). Candidate (5b) has changed PLACE on the stop (the onset segment) and hence incurs a violation of IDENT-PL $)_{\text {Onset }}$ It also violates the generic IDENT-PL.

To conclude, underlying representations and analysis of morphemes exhibiting alternations are uncontroversial. This cannot be said about distributionbased generalizations. The point is illustrated by three processes of American English: Aspiration, Vowel Nasalization and Nasal Assimilation.

(3) a. pea [ $\left.\mathrm{p}^{\mathrm{h}} \mathrm{i}:\right]$, tea $\left[\mathrm{t}^{\mathrm{h}} \mathrm{i}:\right]$, key $\left[\mathrm{k}^{\mathrm{h}} \mathrm{i}:\right]$

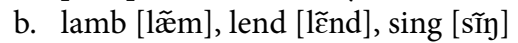

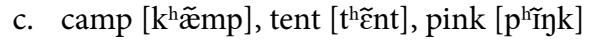

English voiceless stops are aspirated syllable-initially, so, for example, $p$ is as-

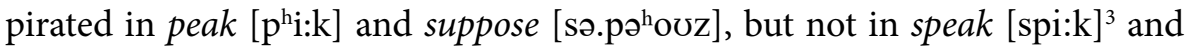
suspect [sə.spekt]. Let us assume that Aspiration is the following markedness constraint.

(4) Aspiration (AsPIR)

Voiceless stops are aspirated syllable-initially.

Aspiration is a powerful generalization in the sense that it is entirely exceptionless and has a clear phonological conditioning. Consequently, no

\footnotetext{
${ }^{3}$ Technically, [sp-] in speak as well as [st-] in stay and [sk-] in sky violate the Sonority Sequencing Generalization (SSG), but English suspends the SSG for [s] plus stop onsets. See Rubach (1997a) and (1999) for discussion.
} 
phonological theory can afford to ignore it. In its nature, Aspiration is different from Nasal Assimilation discussed earlier. The difference is that Aspiration is not based on alternations. The generalization is purely distributional. It is simply a fact that all syllable-initial voiceless stops are aspirated, which means that the occurrence of aspiration is predictable. Standard OT (Prince and Smolensky 2004; McCarthy and Prince 1995) captures distribution-based generalizations by assuming the principle of the Richness of the Base saying that constraints do not hold at the underlying level. Technically, this means that predictable information is accounted for by showing that multiple inputs converge on the same output. Looking at Aspiration as an example, the input for pea can be either /pi:/ with no aspiration or / $\mathrm{p}^{\mathrm{h}} \mathrm{i}$ // with aspirated $/ \mathrm{p}^{\mathrm{h}} /$. Regardless of which of these representations is the input, the grammar correctly selects [ $\mathrm{p}^{\mathrm{h}} \mathrm{i}$ :] as the winner. The correct result is obtained if AsPIR, the driver constraint, outranks the constraint against aspiration.

(5) ${ }^{*}[\mathrm{sg}]: \quad$ Don't have the feature $[\mathrm{sg}]^{4}$

The evaluations in (9) demonstrate that both inputs for pea dictated by the Richness of the Base yield the same result.

(6) $\quad$ i. $\quad / \mathrm{pi}: / \rightarrow\left[\mathrm{p}^{\mathrm{h}} \mathrm{i}:\right]$

\begin{tabular}{|c|c|c|}
\hline & AsPIR & ${ }^{*}[\mathrm{sg}]$ \\
\hline (a) pi: & *! & \\
\hline (b) phi: & & * \\
\hline
\end{tabular}

ii. $/ \mathrm{p}^{\mathrm{h}} \mathrm{i}: /=\left[\mathrm{p}^{\mathrm{h}} \mathrm{i}:\right]$

\begin{tabular}{|c|c|c|}
\hline & ASPIR & $*[\mathrm{sg}]$ \\
\hline (a) pi: & *! & \\
\hline \& $\quad(\mathrm{b}) \mathrm{p}^{\mathrm{h}} \mathrm{i}:$ & & * \\
\hline
\end{tabular}

According to the Richness of the Base, the convergence in (9ib) and (9iib) on the same winner means that aspiration is predictable.

Classic generative phonology, SPE (Chomsky and Halle 1968) but particularly Lexical Phonology (Kiparsky 1982, 1985; Booij and Rubach 1987), uses underspecification to account for distributional generalizations. This is also the tenet of Derivational Optimality Theory (Rubach 2011). ${ }^{5}$ Used in this function, underspecification is guided by what I call the Contextual Predictablility Principle.

\footnotetext{
${ }^{4}$ [sg], which stands for [spread glottis], is the feature denoting aspiration.

${ }^{5}$ The assumptions of this theory are clarified in the next section.
} 
(7) Contextual Predictablility Principle (CPP)

Phonological information that is predictable from context is not encoded in the underlying representation.

Returning to the analysis of aspiration, the CPP predicts that unaspirated stops are present in the underlying representation since aspiration is predictable from context: the syllable-initial position in pea, tea and key. The evaluation of pea is therefore the one in $(9 \mathrm{i}), / \mathrm{pi}: / \rightarrow\left[\mathrm{p}^{\mathrm{h}} \mathrm{i}:\right]$.

Similar reasoning applies to Vowel Nasalization exemplified in (6b), as in lamb [læ̃m]. The distributional fact is that nasal vowels occur only before tautosyllabic nasals in American English (Ladefoged 2001).

(8) Vowel Nasalization (V-NASAL)

Vowels are nasalized before a nasal consonant occurring in the coda.

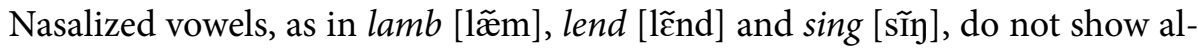
ternations with oral vowels, so the generalization in (11) is motivated solely by distribution: vowels before tautosyllabic nasals are always nasalized, and, conversely, vowels in other contexts are never nasalized. That is, nasalized vowels and oral vowels occur in complementary distribution.

Nasalization offends the segment inventory constraint against nasalized vowels.

(9) ${ }^{*} \mathrm{~V}$ : No nasalized vowels.

Standard OT accounts for the fact that nasalization is predictable by using the principle of the Richness of the Base. In particular, the evaluations of lamb in (13) below demonstrate that the grammar converges on the nasalized vowel output, regardless of whether the input is an oral vowel (13i) or a nasalized vowel (13ii).

(10) i. $/ 1 æ m / \rightarrow[1 \tilde{m}]$

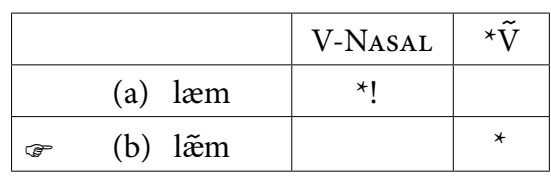

ii. $/ 1 \tilde{x} m /=[1 \tilde{m})$

\begin{tabular}{|c|c|c|}
\hline & V-NASAL & $* \tilde{\mathrm{V}}$ \\
\hline (a) læm & *! & \\
\hline (b) $1 \tilde{a}$ & & * \\
\hline
\end{tabular}

To account for the same facts, classic generative phonology and Derivational OT use underspecification. The Contextual Predictability Principle dictates that the underlying representation of lamb is /læm/ and the evaluation proceeds as in (13i).

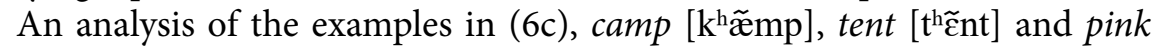
[p ${ }^{\text {hĩnk }}$, combines the generalizations discussed thus far: Aspiration, Vowel Nasalization and Nasal Assimilation. With regard to the latter, the situation is 
different from that shown in (1) because the nasal does not show alternations. Yet, it is clear that the occurrence of [m] in camp, [n] in tent and [n] in pink is not accidental. The nasals could not have been distributed differently, so, for example, ${ }^{\star}[\mathrm{kænp}],{ }^{\star}[\mathrm{t} \varepsilon \mathrm{mt}]$ and ${ }^{\star}[\mathrm{pink}]$ would not be viable words in English. In Standard OT, the job of accounting for this generalization is entrusted to the Richness of the Base. We appear to run into difficulty at this point.

In order to account for the predictability of the place of articulation of the nasal in, for instance, camp, the principle of the Richness of the Base would posit the following input forms: /kæmp/, / kænp/ and / kænp/. But camp also shows predictable aspiration, so both $/ \mathrm{k} /$ and $/ \mathrm{k}^{\mathrm{h}} /$ must be considered as inputs. Further, the occurrence of nasalization on the vowels is also predictable, so we must have both /æ/ and / $\tilde{æ} /$ as inputs. Putting these demands together leads to a formidable number of input representations for the morpheme camp.

(11) a. /kæmp/, /k $\mathrm{k}^{\mathrm{h}} \mathrm{mp} /, / \mathrm{k} \tilde{æ} m p /, / \mathrm{k}^{\mathrm{h}} \tilde{\mathfrak{m}} \mathrm{mp} /$

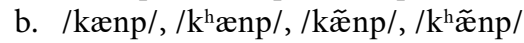

c. $/ \mathrm{kæ \eta p} /, / \mathrm{k}^{\mathrm{h}} \mathfrak{\mathrm { p }} \mathrm{p} /, / \mathrm{k} \tilde{\mathfrak{\eta}} \mathrm{p} /, / \mathrm{k}^{\mathrm{h}} \tilde{\dddot{\eta}} \mathrm{p} /$

This multitude of inputs compromises the idea of the underlying representation. Standard OT's response to this embarras de richesse is to introduce the principle of Lexicon Optimization (Prince and Smolensky 2004). The principle mandates that the most harmonic input, that is, the input that goes through the evaluation incurring the least number of violations, is the underlying representation. In effect, this means that the surface representation is the underlying representation. Viewed in this way, the underlying representation contains all the surface details, including allophonic facts. For the case shown in (14), Lexicon Optimization picks $/ \mathrm{k}^{\mathrm{h}} \widetilde{\mathfrak{x}} \mathrm{mp} /$ as the underlying representation.

Lexicon Optimization solves the embarras de richesse problem but, importantly, does not alleviate the need for multiple inputs to evaluation in order to account for distribution-based generalizations such as Aspiration, Vowel Nasalization and Nasal Assimilation. The Richness of the Base as an analytical procedure runs into difficulty at this point. Let us look at the Nasal Assimilation issue assuming that /kænp/ is the input for camp. For better transparency, the evaluation below ignores the problem of Aspiration and Vowel Nasalization. The icon denotes the wrong winner.

(12) $/ \mathrm{kænp} / \rightarrow\left[\mathrm{k}^{\mathrm{h}} \tilde{\text { mmp}}\right]$ (failed evaluation)

\begin{tabular}{|lc|c|c|c|}
\hline & & NA & IDENT-PL $_{\text {Onset }}$ & IDENT-PL \\
\hline (a) kænp & $*$ ! & & \\
\hline (b) kænt & & & $*$ \\
\hline
\end{tabular}

The evaluation is inconclusive because (15b) and (15c) tie. Actually, the tie is apparent. As is widely agreed upon, labials and dorsals are more marked than 
coronals. Prince and Smolensky (2004) capture this generalization as the ranking ${ }^{\star} \mathrm{LAB} / \mathrm{Dor}$ (don’t be labial; don't be dorsal) $>>{ }^{*} \mathrm{CORON}$ (don't be coronal). Even if bottom-ranked, these constraints break the tie in (15). The icon $*$ denotes the desired winner.

(13) $/ \mathrm{kænp} / \rightarrow\left[\mathrm{k}^{\mathrm{h}} \tilde{\text { mmp}}\right]$ (failed evaluation)

\begin{tabular}{|c|c|c|c|c|c|c|}
\hline & & NA & IDENT-PL) ${ }_{\text {Onset }}$ & IDENT-PL & ${ }^{*} \mathrm{LAB} / \mathrm{DOR}$ & ${ }^{\star}$ CORON \\
\hline & (a) kænp & $* !$ & & & $* *$ & * \\
\hline 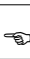 & (b) kænt & & & * & * & * \\
\hline 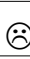 & (c) kæmp & & & * & $* * !$ & \\
\hline
\end{tabular}

${ }^{*} \mathrm{LAB} / \mathrm{Dor}$ is violated in (16a) twice: once by [k] and once by [p]. In (16b), it is violated by $[\mathrm{k}]$ and in $(16 \mathrm{c})$ - by $[\mathrm{k}]$ and $[\mathrm{mp}] .{ }^{*}$ Coron is violated by $[\mathrm{n}]$ in (16a) and by [nt] in (16b). The problem with (16) is that the grammar chooses the wrong winner. The reason for the failure with camp in (16) but the success with the negative prefix in impossible (4) is that IDENT-PL) ${ }_{\text {Onset }}$ is mute in (16) because, unlike in (4), the stop is in the coda rather than in the onset.

An offhand response to this issue might be to introduce positional faithfulness in the coda, like there is positional faithfulness in the onset. Thus, we would have a constraint patterned on (3) but referring to the coda.

(14) Ident-PL) ${ }_{\text {Coda }}$

PLACE on the input segment must be preserved on an output correspondent of that segment in the coda.

This solution and in general constraints such as the one in (17) cannot be correct. First, it is widely known that, in contrast to the onset, the coda is not a position of privilege since phonological distinctions tend to be preserved in the onset but neutralized in the coda (Trubetzkoy 1939). Second, (17) does not make sense from the empirical point of view since not only the stop but also the nasal is in the coda, so (17) would be violated in equal measure by candidate (16b) and candidate (16c). In (16b), /p/ has changed to [t] and the change has taken place in the coda. In (16c), /n/ has changed to [m] and the change, likewise, has taken place in the coda. I conclude that positional faithfulness in the coda is an incorrect idea.

Another way of repairing the failed evaluation in (16) would be to relativize PlaCE to stops and introduce a new constraint such as the following.

(15) Ident-PL) $)_{\text {Stops }}$

Place on a stop consonant in the input must be preserved on a correspondent of that stop in the output.

${ }^{6}[\mathrm{mp}]$ is a single violation of ${ }^{\star} \mathrm{LAB} / \mathrm{DoR}$ as $[\mathrm{m}]$ has the LAB node from spreading, that is, $[\mathrm{m}]$ and $[\mathrm{p}]$ share one node.

${ }^{7}$ Like in the case of [mp], the two consonants share one node; here the Coron node. 
Constraint (18) would deliver the correct result as it would be violated by (16b), where the stop has changed its place of articulation, but not by (16c), where the nasal rather than the stop has altered PLACE.

The problem with (18) is that it opens the way to all kinds of new constraints whose merit might be hard to justify. Once we admit (18), nothing stands in the way of proposing any number of similarly structured constraints, for example, IDENT-PL) $)_{\text {Fricatives }}$ IDENT-PL) $)_{\text {Nasals }}$ IDENT-PL $)_{\text {Laterals }}$ IDENT-PL) Labials $_{\text {IDENT-PL) }}$ Coronals IDENT-PL) $_{\text {Dorsals }}$, and so forth. Notice that IDENT-PL) $)_{\text {Stops }}$ is in fact IDENT$\mathrm{PL})_{[- \text {-sonor-contin] }}$ because stops as such do not function as a primitive in feature geometry (Clements 1985; Halle 1992; Sagey 1986 and others). Given that, IDENT constraints could potentially be relativized to any element of the feature tree, including absurd combinations, for instance, IDENT[+nasal] $)_{[\text {-voice] }}$. I conclude that postulating (18) has undesirable consequences. These are of two types. First, the theory is expanded by potentially adding a huge number of new constraints. Second, given the expansion, we lose control of the ways in which elements of feature geometry are combined to predict patterns attested in natural languages.

The difficulties just described do not occur if we abandon the Richness of the Base as a method of accounting for predictable patterns in non-alternating forms and adopt the Contextual Predictablility Principle (CPP).

The CPP mandates that properties that are predictable in a given context be removed from the underlying representation of morphemes. In the case at hand, the predictable property is the place of articulation of the nasal. Consequently, the CPP demands that the nasal be underspecified for PLACE. Therefore, the underlying representations of our examples camp, tent and pink are / $\mathrm{kæNp} /$, /teNt/ and /piNk/, respectively, with the archiphoneme /N/ that is underspecified for Place. Similarly, the properties of Aspiration and Vowel Nasalization are also underspecified, so plain stops and oral vowels occur in the underlying representations, as just shown.

The evaluation of camp is straightforward. All the necessary constraints are already in place, so the evaluation proceeds as follows.

(16) $/ \mathrm{kæNp} / \rightarrow\left[\mathrm{k}^{\mathrm{h}} \tilde{\mathfrak{m}} \mathrm{mp}\right]$

\begin{tabular}{|c|c|c|c|c|c|c|}
\hline & NA & IDENT-PL & ASPIR & V-NASAL & ${ }^{*}[\mathrm{sg}]$ & ${ }^{\star} \tilde{\mathrm{V}}$ \\
\hline (a) $\mathrm{k}^{\mathrm{h}} \tilde{\mathfrak{x}} \mathrm{Np}$ & $* !$ & & & & * & * \\
\hline (b) $\mathrm{k}^{\mathrm{h} \tilde{æ} n \mathrm{p}}$ & $* !$ & & & & * & $\star$ \\
\hline (c) $\mathrm{k}^{\mathrm{h}} \tilde{\mathfrak{x}} \mathrm{nt}$ & & $* !$ & & & * & $\star$ \\
\hline (d) $k^{\text {h } \tilde{x} y p ~}$ & $*$ ! & & & & * & $\star$ \\
\hline (e) $\mathrm{k}^{\mathrm{h}} \tilde{\mathfrak{x}} \mathrm{mp}$ & & & & & * & $*$ \\
\hline (f) kæ̃mp & & & *! & & & * \\
\hline (g) $k^{\text {h }}$ & & & & *! & * & \\
\hline
\end{tabular}


Since the input nasal is underspecified for Place, Ident-Pl demanding that PlaCE be preserved in an output correspondent is by definition mute. Candidate (19c) violates IDENT-PL not because of the nasal but because underlying $/ \mathrm{p} /$, a labial, has changed to [t], a coronal, so the LAB property of the stop has not been preserved in the output. The evaluation in (19), modeled in terms of underspecification, is a complete analysis of the distribution-driven generalizations in camp. In contrast, Standard OT's analysis in terms of the Richness of the Base assumes 12 different inputs shown in (14) and runs 12 evaluations. This complexity is further magnified by the need to solve the directionality problem: the candidates [kænt] versus [kæmp] in camp. The solution is not available within the current theory, so it is necessary to expand the theoretical apparatus of OT, an undesirable consequence. I conclude that underspecification provides a better analysis than the Richness of the Base. In the next section I inspect some predictions made by Lexicon Optimization with regard to underlying representations.

\section{Lexicon Optimization and URs: Retraction}

This section addresses the issue of whether Lexicon Optimization selects the correct candidate as the underlying representation. The illustrative material comes from the operation of Retraction, $i \rightarrow \mathrm{i}$, in words borrowed into Polish from languages that have no [i]. I argue that Lexicon Optimization leads the analysis in the wrong direction, predicting forms that are exactly the opposite of the desired forms. The correct analysis is one that is based on underspecification dictated by the Contextual Predictability Principle.

Presentation of the analytical material from borrowings needs to be prefaced with an explanation of how Palatalization triggered by $i$ is analyzed in Slavic languages in terms of OT. To clarify this issue, I look at some examples from Russian.

(17) Russian Palatalization and Retraction

a. brat [brat] 'brother' - brat+ik [bratijk] (diminutive)

Palatalization: $t \rightarrow t^{j}$ before $i$

b. Ivan [ivan] 'Ivan' - brat Ivana [brat ivana]

Retraction: $i \rightarrow \dot{i}$ after a hard consonant

Let me clarify that consonants in both Russian and Polish are either hard (velarized) or soft (palatalized) and there are no neutral consonants (Avanesov 1968 for Russian; Wierzchowska 1963, 1971 for Polish). Secondary articulations of velarization and palatalization are characterized in terms of the feature $[ \pm$ back]: hard consonants carry the feature [+back] while soft consonants carry the feature [-back]. In the Slavic tradition, softness, but not hardness, is marked on the consonant, so [t] is soft while $[\mathrm{t}]$ is hard. 
The changes in (20) might appear to be unrelated since Palatalization affects the consonant while Retraction changes the vowel. In actuality, however, Palatalization and Retraction are two sides of the same coin: they constitute a classic case of phonological conspiracy that OT has been designed to handle. The conspiracy is to eliminate [Ci], that is, a sequence of segments that disagree in [ \pm back]: the consonant is hard (velarized) and hence [+back] while the vowel is front and hence [-back]. Palatalization brings [Ci] to agreement in backness at the expense of the consonant since it is the consonant that yields to the vowel and changes from [+back] (velarization) to [-back] (palatalization). The result is a perfect harmony: both the consonant and the vowel are [-back]. Retraction achieves the same harmony but at the expense of the vowel that yields to the hard (that is [+back]) consonant and changes from [-back] to $[+$ back $], i \rightarrow i .^{8}$

The Palatalization - Retraction conspiracy is expressed as the following constraint (Rubach 2017).

(18) PAL- $i$

A consonant and a following unrounded high vowel must agree in $[ \pm$ back].

PAL $-i$ is the driver for Palatalization and Retraction. The choice of one or the other process is a matter of how the following faithfulness constraints are ranked.

(19) a. IDENT-C $[ \pm$ back $]$

The value of $[ \pm$ back $]$ on the input consonant must be preserved on a correspondent of that consonant in the output.

b. IDENT-V $[ \pm$ back $]$

The value of $[ \pm$ back] on the input vowel must be preserved on a correspondent of that vowel in the output.

The interaction of the constraints is illustrated in (23).

(20) i. Palatalization, $C \rightarrow C^{\mathrm{j}}$

$/$ brat $+\mathrm{ik} / \rightarrow$ [bratijk] 'brother' (dimin.)

\begin{tabular}{|lc|c|c|c|}
\hline & & PAL- $i$ & IDENT-V $[ \pm$ back $]$ & IDENT-C $[ \pm$ back $]$ \\
\hline (a) bratik & $* !$ & & \\
\hline (b) bratiik & & & $*$ \\
\hline (c) bratik & & $* !$ & \\
\hline
\end{tabular}

${ }^{8}$ The vowel [i] in both Russian and Polish is central, but, uncontroversially, central vowels are characterized as [+back]. For arguments showing that $/ \mathbf{i} /$ is an underlying segment in Polish, see Rydzewski (2017). 
ii. Retraction, $i \rightarrow \mathbf{i}$

/brat ivana/ $\rightarrow$ [brat ivana] 'Ivan's brother'

\begin{tabular}{|c|c|c|c|}
\hline & PAL- $i$ & IDENT-C $[ \pm$ back $]$ & IDENT-V $[ \pm$ back $]$ \\
\hline (a) brat ivana & $\star$ & & \\
\hline (b) brat ivana & & $* !$ & \\
\hline (c) brat ivana & & & $*$ \\
\hline
\end{tabular}

The rankings in (23i) and (23ii) are contradictory, so Standard OT cannot accommodate them and hence predicts that Palatalization and Retraction cannot occur in the same language. The trouble is that they do occur in the same language. The language is Russian (also Polish - see later), as the adduced examples show. I conclude that Standard OT makes the wrong prediction.

This criticism cannot be levied against Derivational OT (Kiparsky 1997, 2000; Rubach 1997b, 2000a, 2000b; Bermúdez-Otero 1999) called also Stratal OT (McCarthy 1999). The tenet of this theory is that the grammar is organized into subcomponents called levels. Rubach (1997b) uses two levels: the lexical level and the postlexical level. Kiparsky's (2000) proposal is to recognize three levels: the stem level, the word level and the postlexical level. This proposal is extended by Rubach (2011) to include one more level: the clitic level placed between the word level and the postlexical level. As just noted, each level is associated with a morphological domain: the stem, the word, the clitic phrase and the sentence, respectively. All constraints are present at all levels but their ranking may be different at different levels. The default assumption is to maintain the same ranking at all levels, so reranking between levels is minimized (Rubach 2000a) and requires motivation. The input to level 1 (the stem level) is the underlying representation. The input to level 2 (the word level) is the winner from level 1 . The input to level 3 (the clitic level) is the winner from level 2, and, predictably, the input to level 4 (the sentence level) is the winner from level 3. In effect, every level constitutes a 'miniphonology' with its own inputs and constraint ranking.

The contradiction in (23) is not a problem for Derivational OT: Palatalization occurs at the word level, where the ranking is IDENT-V $[ \pm$ back $]>>$ IDENT$\mathrm{C}[ \pm$ back $]$. This ranking is reversed at the postlexical level, IDENT-C $[ \pm$ back $]>>$ IDENT-V $[ \pm$ back], the result being that we witness Retraction.

With this background, we are ready to look at borrowings into Polish involving the vowel $i$. A representative sample of recent borrowings is given in (24).

(21) Borrowings into Polish optimum [tij] 'optimum' tiramisu [tii] 'type of cake' dinozaur [dii] 'dinosaur'

maksimum [sij] 'maximum' Zimbabwe [zii] 'Zimbabwe' Zanzibar [zii] 'Zanzibar' 
grill [rij] 'grill'

Riwiera [rij] 'Riviere'

Cicero [tsij] 'Cicero'

dżin $\mathrm{z}$ tonikiem [d $\mathrm{d}^{\mathrm{ji}}$ ] 'gin and tonic'
Hiroszima [j]i] 'Hiroshima'

czipsy [t]ji] 'chips'

$d \dot{z} i$ hadysta [djii] 'jihadist'

Standard OT with its principle of Lexicon Optimization and Derivational OT with the Contextual Predictability Principle (CPP) make radically different predictions for the data in (24). Lexicon Optimization assumes structures with palatalized consonants $/ / \mathrm{Cij}^{\mathrm{i} /} / /^{9}$ as underlying representations because there are no alternations and palatalized consonants are the segments occurring on the surface, so optimum, dinozaur, maksimum, Zanzibar, grill Hiroszima and so forth derive from //tij//, // $\mathrm{dij}^{\mathrm{i}} / /$, //sij//, //zij//, //rij//, // $\mathrm{ji} / /$, respectively. Derivational OT comes up with different representations because it is guided by the CPP and not by Lexicon Optimization. Since palatalization is predictable before [i], the CPP mandates that [-back], that is, the feature representing palatalization, be removed from the underlying representation, so the words in (24) are represented as underlying //Ci// rather than //Cii//. Specifically, for the examples just quoted, we have the following underlying representations: //ti//, //di// //si//, //zi//, //ri//, // Ji//. Since [-back] (palatalization) has been removed from these representations, the consonants are hard, that is, they carry the feature [+back] because, as noted earlier, Polish, like Russian, has no neutral consonants: a consonant is either [-back] or [+back]. ${ }^{10}$

The Lexicon Optimization analysis, with underlying $/ / \mathrm{C}^{\mathrm{j}} \mathrm{i} / /$, raises two questions:

(22) a. Why don't // $\mathrm{t}^{\mathrm{j}} \mathrm{d}^{\mathrm{j}} \mathrm{s}^{\mathrm{j}} \mathrm{Z}^{\mathrm{j} / /}$ assimilate to the native pattern of Polish and become prepalatal [ to dz $6 \mathrm{z}]]^{\text {?1 }}$

b. Why are $[\mathrm{Cii}]$ forms unstable and limited to foreign words?

Question (25b) is important because, as will be shown below, assimilation of borrowings is carried out by PAL-i. But, if the underlying representation is // $\mathrm{Cij} / /$, PAL- $i$ is not violated and hence cannot function as an agent of assimilation and the driver for changes in the output candidates.

${ }^{9}$ Since Derivational OT distinguishes underlying representations and intermediate representations (inputs to levels 2, 3 and 4), the former are enclosed in double slashes and the latter in single slashes. Surface representations, as usual, are written in square brackets.

${ }^{10}$ Removing the feature [+back] in order to arrive at archiphonemes that are underspecified for $[ \pm$ back] is technically possible, but there is no advantage to such an analysis. The CPP (Contextual Predictability Principle) does not have jurisdiction here because velarization, unlike palatalization, is not determined contextually.

${ }^{11} \mathrm{I}$ omit // $\mathrm{r} / /$ because it causes additional complications by changing to [3]; see Rubach (1984). 
The remainder of this section is devoted to answering the questions in (25). The answers lie in the various ways in which PAL-i functions in Polish. They are outlined briefly below. ${ }^{12}$

PAL- $i$ is active at all derivational levels. At level 1 (the stem level), PAL- $i$ functions in its capacity as a palatalization process. Its jurisdiction is limited to derived environments in the morphological sense, that is, PAL- $i$ looks only at structures that span a morpheme boundary, $C+i$, and is blind to structures that are contained wholly inside a morpheme, $\mathrm{Ci}$.

(23) sklep [p] 'shop'

$\mathrm{klu} b+\mathrm{y}[\mathrm{b}]$ 'clubs'13

tom $[\mathrm{m}]$ 'volume'

bat $[\mathrm{t}]$ 'whip'

samochod+y [d] 'cars'

głos [s] 'voice'

zraz+y $[z]$ 'hamburgers'

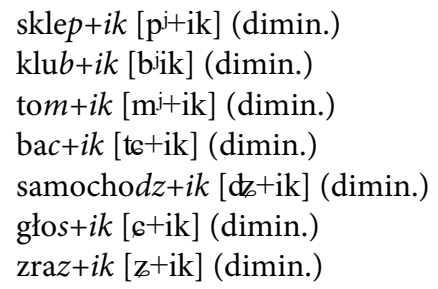

PAL-i palatalizes the consonant, $C \rightarrow C^{j}$, as seen clearly in the case of labials. Coronals //t d s z// change ultimately to prepalatal stridents (stops become affricates) [to d $\left.\mathrm{d}_{6} \mathrm{z}\right]$. At level 1 , we see only $C \rightarrow C^{j}$, so $/ / \mathrm{t} \mathrm{d} \mathrm{s} \mathrm{z//} \rightarrow / t^{\mathrm{j}} \mathrm{d}^{\mathrm{j}} \mathrm{s}^{\mathrm{j}} \mathrm{z}^{\mathrm{j}} /$, like $/ / \mathrm{p} \mathrm{b} \mathrm{m} / / \rightarrow / \mathrm{p}^{\mathrm{j}} \mathrm{b}^{\mathrm{j}} \mathrm{m}^{\mathrm{j}} /$. The further step of spelling out palatalized coronals as

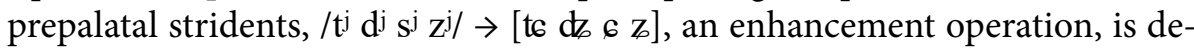
layed until Level 2. ${ }^{14}$ Level 2 (the word level) witnesses also active PAL-i, but this time PAL- $i$ applies in its capacity as Retraction, $i \rightarrow i$. The restriction to derived environments does not hold at level 2, so Retraction affects structures both inside morphemes and across morpheme boundaries. The examples in (27) contain the same diminutive suffix //ik// as the examples in (26).

(24) piec [ts] 'oven' $\mathrm{ryd} z[\mathrm{ts}]^{15}$ 'type of mushroom' $\operatorname{deszcz}[\mathrm{t}]$ ' 'rain' kosz [J] 'basket' baga $\dot{z}\left[\int\right]$ 'baggage' żołnie $r z[S]$ 'soldier'

$$
\begin{aligned}
& \text { piec }+y k \text { [tsik] (dimin.) } \\
& \text { rydz+yk [dik] (dimin) } \\
& \text { deszcz+yk [tjik] (dimin.) } \\
& \text { kosz+yk [jik] (dimin.) } \\
& \text { baga } z+y k \text { [jik] (dimin.) } \\
& \text { żołnierz+yk [3ik] (dimin.) }
\end{aligned}
$$

The suffix //ik// shown overtly as surface [ik] in (26) appears as [ik] in (27), so we see Retraction after a hard consonant, ${ }^{16}$ an effect of PAL- $i$ bringing the

\footnotetext{
${ }^{12}$ For reasons of space, it is not possible to lay out the details of Polish Palatalization. For discussion, see Rubach (1984, 2003b, 2017).

${ }^{13}$ I give the plural form because in the singular klub undergoes Final Devoicing, [klup], so there is no $[\mathrm{b}]$.

${ }^{14}$ The reason for this delay is to avoid confusion between the posterior stridents / to d $6 \mathrm{zl}$ derived from $/ / \mathrm{t} \mathrm{d} \mathrm{s} \mathrm{z//} \mathrm{and} \mathrm{the} \mathrm{posterior} \mathrm{stridents} / \mathrm{t}^{\mathrm{j}} \mathrm{d}^{\mathrm{j}} \mathrm{J}^{\mathrm{j} /}$ derived from underlying velars $/ / \mathrm{k}$ g x//. See Rubach $(1984,2003 b, 2017)$ for discussion.

${ }^{15}[\mathrm{ts}]$ and [S] below are an effect of Final Devoicing.

${ }^{16}$ See Rubach (1984) for descriptive generalizations regarding Retraction.
} 
consonant and the vowel into agreement by assimilating the front [-back] vowel to the hard [+back] consonant, yielding [Ci], where both segments are [+back].

At level 3 (the clitic level) and level 4 (the sentence level), PAL- $i$ returns to its Palatalization function familiar from level 1. This time, however, the effect of PAL-i, $C \rightarrow C^{j}$, is the final output and there is no spell-out enhancement to

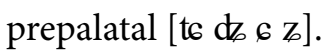

(25) a. Level 3 (the clitic level): $C \rightarrow C^{J}$ inspektor 'inspector'

ignorować 'ignore'

izba 'room'

nad+inspektor $\left[\mathrm{dij}^{17}{ }^{17}\right.$ 'superintendant' nad inspektorem [dii] 'above the inspector' $z+$ ignorować [zi] 'ignore' (perfective) $z$ izby [zj i] 'from the room'

b. Level 4 (the sentence level): $C \rightarrow C^{j}$ sklep Ireny [ $\left.\mathrm{p}^{\mathrm{j}} \mathrm{i}\right]$ 'Irene's store' tron Ireny $\left[n^{\mathrm{j}} \mathrm{i}\right]$ 'Irene's throne' brat Ireny [ $\mathrm{t} \mathrm{i}]$ 'Irene's brother piec Ireny [ $\left.\mathrm{s}^{\mathrm{j}} \mathrm{i}\right]$ 'Irene's oven' kosz Ireny [j] i] 'Irene's basket'

dom Ireny [ $\left.\mathrm{m}^{\mathrm{j}} \mathrm{i}\right]$ 'Irene's house' bar Ireny [ $\left.\mathrm{r}^{\mathrm{j}} \mathrm{i}\right]$ 'Irene's bar' głos Ireny [ $\left.\mathrm{s}^{\mathrm{j}} \mathrm{i}\right]$ 'Irene's voice' płaszcz Ireny [ $\left[\mathrm{g}^{\mathrm{j}} \mathrm{i}\right]$ 'Irene's coat' baga $z \dot{z}$ Ireny[ $\left[{ }^{j} i\right]$ 'Irene's baggage'

Bearing in mind this outline of how PAL-i functions in Derivational OT, we return to the questions posed in (25). The first question is why the representa-

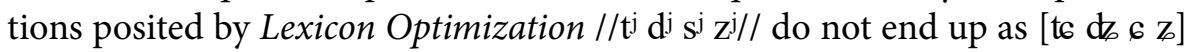
when borrowings such as those in (24), for instance, optimum 'optimum', are assimilated to the native pattern. The question concerns the operation of two constraints. The details are as follows.

The enhancement spell-out $/ \mathrm{t}^{\mathrm{j}} \mathrm{d}^{\mathrm{j}} \mathrm{s}^{\mathrm{j}} \mathrm{z}^{\mathrm{j} /} \rightarrow\left[\begin{array}{ll}\mathrm{t} 6 \mathrm{~d} & \mathrm{~d} \\ \mathrm{z}\end{array}\right]$ is executed by two constraints (Rubach 2003b).

(26) a. Posteriority (Posterior)

Palatalized coronals must be [-anter].

b. Stridency (STRID)

Palatalized coronals must be [+strid].

We are looking here at two independent constraints rather than at one constraint, as the following cross-linguistic data show.

(27) a. Slovak Palatalization

Palatalized dental stops change the place of articulation from dental to prepalatal (Rubach 1993).

$/ \mathrm{t}^{\mathrm{j}} \mathrm{d}^{\mathrm{j} /} \rightarrow\left[\mathrm{t}^{\mathrm{j}} \mathrm{d}^{\mathrm{j}}\right]$, where underlining means 'prepalatal' advokát [t] 'lawyer' advokát+ik [tijik] (dimin.) had [t] 'reptile' had+ík [dii:k] (dimin.)

${ }^{17}$ There is nothing unusual about the fact that prefixes are processed at level 3 (the clitic level) since historically prefixes come from prepositions; compare this word with the phrase below. 
b. Vilnius Palatalization

Palatalized dental stops change into palatalized dental affricates (Rubach 2003b). $/ \mathrm{t}^{\mathrm{j}} \mathrm{d}^{\mathrm{j} /} \rightarrow\left[\mathrm{ts}^{\mathrm{j}} \mathrm{d}^{\mathrm{j}}\right]$

$$
\begin{aligned}
& \text { bat [t] 'whip' bactik [tsik] (dimin.) } \\
& \text { samochód [t] 'car' samochodz+ik [zjik] (dimin.) }
\end{aligned}
$$

c. Polish Palatalization

Palatalized dental stops change into prepalatal affricates and fricatives.

$/ \mathrm{t}^{\mathrm{j}} \mathrm{d}^{\mathrm{j}} \mathrm{s}^{\mathrm{j}} \mathrm{Z}^{\mathrm{j} /} \rightarrow[\mathrm{tc} \mathrm{d} \mathrm{b} \quad \mathrm{z} \mathrm{z}]$

$$
\begin{array}{ll}
\text { bat }[\mathrm{t}] \text { 'whip' } & \text { bac }+i k[\mathrm{tcik}](\text { dimin.) } \\
\text { samochód }[\mathrm{t}] \text { 'car' } & \text { samochodz+ik [dik] (dimin.) }
\end{array}
$$

In Slovak, palatalized dentals become prepalatals without being affricated, so Posterior (29a) is active while STrID (29b) is not. In Vilnius Polish, the situation is reversed: palatalized dentals become affricates without being retracted to the prepalatal place of articulation, so STRID (29b) is active while POSTERIOR (29a) is not. In Standard Polish, both of these constraints are active: palatalized dentals become prepalatal due to POSTERIOR and stops become affricates due to STRID (29b). These changes violate the following IDENT constraints.

(28) a. IDENT [ \pm anter]

The value of $[ \pm$ anter] on the input consonant must be preserved on a correspondent of that consonant in the output.

b. IDENT $[ \pm$ strid]

The value of $[ \pm$ strid] on the input consonant must be preserved on a correspondent of that consonant in the output.

The evaluation of $b a c+i k$ 'whip' (dimin.) is now as follows. Recall that $/ / \mathrm{t} / / \rightarrow /$

\begin{tabular}{|c|c|c|c|c|c|}
\hline & & Posterior & STRID & IDENT $[ \pm$ anter $]$ & IDENT $[ \pm$ strid $]$ \\
\hline (a) & batijik & $* !$ & * & & \\
\hline (b) & bat ${ }^{\mathrm{j} j \mathrm{ik}}$ & & $* !$ & * & \\
\hline (c) & batsijk & $* !$ & & & * \\
\hline$\leftrightarrow \quad(d)$ & batcik & & & * & * \\
\hline
\end{tabular}
$\mathrm{t}$ / / has already been effected at level 1 , so the input to level 2 , the winner from Level 1 , is /batiik/.

(29) Level 2 /batijk $\rightarrow$ [batcik]

A Lexicon Optimization analysis of Standard OT that posits //tij// as the underlying representation in optimum 'optimum' and the like runs into a problem with the $/ \mathrm{t} / \mathrm{j} / \mathrm{t} \mathrm{t}]$ spell-out at level 2 . Specifically, since optimum does not end up with [t6], the input //tii// must be marked as an exception to the $/ \mathrm{t}^{\mathrm{j}} \mathrm{d}^{\mathrm{j}} \mathrm{s}^{\mathrm{j}} \mathrm{z}^{\mathrm{j}} /$

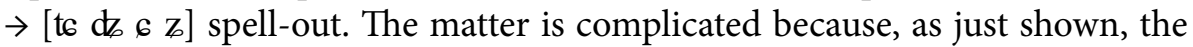
spell-out consists of two independent constraints: Posterior and STRID, so optimum is exceptional in two different ways. 
The natural expectation is that the exceptionality markings are eliminated in the process of assimilating borrowings, here optimum, to the native pattern, so that borrowings are like native words. In the case at hand, fulfilling this expectation would mean that optimum succumbs to POSTERIOR and STRID and starts being pronounced with [tc] as [optcimum]. However, this is not what happens. The attested facts from variation as well as historical change (see below) make it perfectly clear that this line of reasoning is on the wrong track, so the Lexicon Optimization approach of Standard OT fails by making the wrong prediction.

One wonders if the Lexicon Optimization analysis could not be rescued in some way. The question is whether we could make use of the fact that the $/ / \mathrm{ti} / /$ of optimum that does not change to [t6i] is present in the underlying representation while the $/ \mathrm{t} \mathrm{i} /$ of $b a c+i k$ 'whip' (dimin.) that is spelled out as [tci] is derived, not underlying. The answer is negative: this difference cannot be captured in OT. First, to capture the difference we would need to postulate IDENT constraints saying "preserve the feature [+anter] on the consonant that is palatalized in the underlying representation" and similarly "preserve the feature [-strid] on the consonant that is palatalized in the underlying representation". Such constraints are not admissible in OT. Second, the architecture of Derivational OT does not permit making a distinction between these level 2 inputs that correspond to the level 1 inputs (the underlying representations) and those level 2 inputs that do not correspond to the level 1 inputs (the underlying representations). Specifically, the input to level 2 exemplified by optimum is / $\mathrm{ti \textrm {i }}$ / corresponding directly to the underlying $/ / \mathrm{ti \textrm {i }} / /$ postulated by the Lexicon Optimization approach. There is no way to make this / $\mathrm{t} \mathrm{i} / \mathrm{be}$ have differently from the level 2 input $/ \mathrm{t} \mathrm{ij} / \mathrm{that}$ was derived at level 1 from underlying $/ / \mathrm{t}+\mathrm{i} / /$, as in $b a t$ 'whip' - bac $+i k$ (dimin.), //bat $+\mathrm{ik} / / \rightarrow / \mathrm{batik} /$ at level 1 . That is, from the point of view of level 2 , the $/ \mathrm{t} \mathrm{i}$ / of optimum and the $/ \mathrm{ti}$ / of $b a c+i k$ are exactly the same. They are both inputs to level 2, figuratively, they are both "level 2 underlying representations", so they must behave in the same way towards all faithfulness constraints. I conclude that the Lexicon Optimization analysis with underlying //ti $\mathrm{i} / /$ in optimum is simply incorrect and must be rejected.

The problem just discussed does not exist in the underspecification approach adopted by Derivational OT. As noted earlier, the Contextual Predictability Principle postulates underlying //ti// rather than // $\mathrm{ti} / /$ in optimum by removing the predictable [-back] property from the surface [ $\left.\mathrm{ti}_{\mathrm{i}}\right]$. The input to level 2 is therefore /ti/ with hard / $/ \mathrm{t} /$ rather than soft $/ \mathrm{t} \mathrm{j} /$. This means that the spell-out constraints Posterior and STRID are mute because they are activated by palatalized consonants, hence by $/ \mathrm{t} /$, but not by $/ \mathrm{t} /$. The result is that, unlike Standard OT with its principle of Lexicon Optimization, Derivational OT does not make the prediction that optimum should be pronounced as 
[optcimum] once it is fully assimilated to the native pattern. This prediction is correct.

The evidence from variation and from historical change shows conclusively that the nativization pattern for coronals followed by $i$ morpheme-internally is to use Retraction and not Palatalization: $t i \rightarrow t i$ rather than $t i \rightarrow t c i$. So, the fully assimilated pronunciation of optimum is [optimum], not [optimum] or [optcimum]. The Lexicon Optimization approach with its underlying //tij// has no story to tell about Retraction as the nativization pattern. Since, given underlying $/ / \mathrm{t} \mathrm{i} / /$, both the consonant and the vowel are [-back], PAL- $i$ is satisfied and there is no incentive to change $/ / \mathrm{tij} / /$ into any other structure since surface [ $\mathrm{ti}$ ] does occur in Polish. The [Cii] structures occur on a massive scale because they are derived by PAL- $i$, applying at level 3 and level 4 (recall (28) earlier in this section).

The situation looks radically different from the point of view of the underspecification approach prompted by the Contextual Predictablility Principle. The input to level 2, which is the underlying representation in the case of optimum, has //ti// that disobeys PAL- $i$ because the consonant is hard (that is [+back]) while the vowel is front (that is [-back]). This violation of PAL- $i$ drives assimilatory changes. The predicted outcome of assimilation is that /ti/ will turn into [ti] because, as noted earlier (recall (27) earlier in this section), the result of PAL- $i$ at Level 2 is Retraction and not Palatalization. This claim is substantiated by evidence from historical change and from variation.

There is a massive body of data that documents Retraction after hard coronals morpheme-internally. Some representative examples are the following. ${ }^{18}$

(30) German Risiko $\rightarrow$ ryzyko [riziko] 'risk'

Kontinent $\rightarrow$ kontynent [kontinent] 'continent'

Korrepetitor $\rightarrow$ korepetytor [korepetitor]

Direktor $\rightarrow d y$ rektor [direktor] 'director'

Schiene $\rightarrow$ szyna [Jina] 'rail'

Latin consilium $\rightarrow$ konsylium [konsilijum] 'counseling'

French cousin $\rightarrow$ kuzyn [kuzin] ${ }^{19}$ 'cousin'

critique $\rightarrow$ krytyka [kritika] 'criticism'

Gilette $\rightarrow \dot{z} y$ letka [3ilktka] 'razor'

English bridge $\rightarrow$ brydż [britg]

As these examples document, Retraction and not Palatalization is the nativization strategy for borrowings containing a coronal followed by $i$. The same conclusion emerges from the inspection of variation. All the words cited earlier in (24) for $\left[\mathrm{Cii}^{\mathrm{i}}\right]$ have an alternative pronunciation with $[\mathrm{Ci}]$.

\footnotetext{
${ }^{18}$ Most examples come from Sławski (1952).

${ }^{19}$ This is a graphic borrowing; phonetically the vowel in French is $[\tilde{\varepsilon}]$.
} 
(31) Variation $[\mathrm{Cji}] \sim[\mathrm{C} \dot{i}]$

optimum [tii] $\sim$ [ti] 'optimum'

tiramisu $[\mathrm{tij}] \sim[\mathrm{ti}]$ 'type of cake'

dinozaur $\left[\mathrm{d}^{\mathrm{ji}}\right] \sim[\mathrm{di}]$ 'dinosaur'

grill [rij] $\sim$ [ri] 'grill'

Riwiera [rij] [ri] 'Riviere'

$d \dot{z} i$ hadysta [dzji] $\sim$ [dzi] 'jihadist'

$d \dot{z}$ in $\mathrm{z}$ tonikiem [dzji] [dji] 'gin and tonic' maksimum [sji] [si] 'maximum'

Zanzibar $\left[z^{j i}\right] \sim[\mathrm{zi}]$ 'Zanzibar'

Zimbabwe $\left[\mathrm{z}^{\mathrm{ji}}\right] \sim[\mathrm{zi}]$ Zimbabwe'

Hiroszima [ $[\mathrm{ji}] \sim\left[\int \mathrm{j}\right]$ 'Hiroshima'

czipsy $[\mathrm{t} j \mathrm{ji}] \sim[\mathrm{tgi}]$ 'chips'

Cicero [tsi] $\sim$ [tsi] 'Cicero'

It is crystal clear that the assimilation of borrowings goes in the direction of Retraction after coronals. For example, the adjectives optymal $+n+y$ [optimalni] 'optimal' and maksymal $+n+y$ [maksimalni] 'maximal' are pronounced only with [i], never with [i], even though the corresponding nouns optimum 'optimum' and maksimum 'maximum' show variation [i] [i]. The adjectives were borrowed separately from the nouns, which is indicated, among other things, by the fact that the foreign forms optimal and maximal are adjectives themselves and yet they were adjectivized anew by adding the Polish adjectiveforming suffix $-n$, as in brud 'dirt' - brud $+n+y$ 'dirty'.

There is much sociolinguistics involved in determining which of the variable forms in (34) is actually used. The main factors are education and degree of formality: the higher the degree of education and the higher the degree of formality, the less likely it is that the assimilated forms with [i] will be used. Certain "learned" words, such as sinologia 'sinology', that are known only to highly-educated speakers, are probably never pronounced with [i]. Also conversely, the word grill, which is widely used, is typically pronounced with [i] while the verb grillować 'to grill', in which grill is nativized further by the Polish verbalizing suffix $o w a$, is almost exclusively pronounced with [i] .

Generally speaking, when words with a coronal followed by $i$ are borrowed, they start their life in Polish as [Cii] with palatalization. The process of nativization turns the facts around and produces [Ci]. The question is how this general observation can be incorporated into the grammar.

As already noted, the Lexicon Optimization approach assumed by Standard OT with its principled attachment to phonetic detail bets its money on the wrong facts and picks //Cii// as the underlying representation because $[\mathrm{Cii}]$ is the attested surface form. This analysis has no story to tell about the transition from $\left[\mathrm{Cij}^{\mathrm{i}}\right]$ to $[\mathrm{Ci}]$ in the process of assimilation to the native pattern. The reason is that //Cii// obeys PAL- $i$ (both the consonant and the vowel are [-back]), so there is no incentive to introduce any changes.

In contrast, Derivational OT, which is guided by the Contextual Predictability Principle, has a credible scenario for the transition from [Cii] to [Ci]. The point is illustrated by $t i$ in optimum 'optimum'. As argued earlier, the underlying representation is $/ / \mathrm{ti} / /$, with a hard $/ / \mathrm{t} / /$ and a front vowel $/ / \mathrm{i} / /$. This configuration violates PAL- $i$ because the consonant is [+back] while the vowel is 
[-back]. In spite of the violation, nothing happens at level 1 because PAL- $i$ is limited to derived environments at level 1 and /ti/ is contained wholly inside one morpheme. The result is that the underlying //ti// leaves level 1 as /ti/ and hence / $\mathrm{ti}$ / is the input to level 2. At level 2, PAL- $i$ is no longer bound to derived environments and the normal procedure is to retract the vowel after a hard consonant, $i \rightarrow i$. The fact that the $/ \mathrm{i} / \mathrm{in} / \mathrm{ti} /$ does not undergo Retraction is an irregularity. The morpheme containing /ti/ must be marked as an exception to PAL- $i$ at level $2 .{ }^{20}$ As already explained (see (28) above), at level 3 and at level 4, PAL-i reverts to its function as the driver for Palatalization rather than Retraction. The output from level 2, /ti/ (with /i/ rather than /i/ due to exceptionality), undergoes Palatalization, $/ \mathrm{ti} / \rightarrow[\mathrm{ti}]$, which is the attested surface form of the unassimilated variant of optimum 'optimum'.

(32) Level 3 /optimum/ $\rightarrow$ [optiimum]

\begin{tabular}{|l|c|c|c|}
\hline & PAL- $i$ & IDENT $-V[ \pm$ back $]$ & IDENT $-C[ \pm$ back $]$ \\
\hline (a) optimum & $*$ ! & & \\
\hline \multirow{*}{*}{ (b) optiimum } & & & $*$ \\
\hline (c) optimum & & $* !$ & \\
\hline
\end{tabular}

As noted earlier, the spell-out constraints, POSTERIOR and STRID, not shown in (35), are inactive at Level $3,{ }^{21}$ so there is no danger that [tii] will be spelled out as $*$ tci].

In this analysis, the nativization $/ \mathrm{ti} / \rightarrow$ [ti] is an effect of the grammar eliminating exceptionality. The pressure to regularize the grammar ultimately wins in the competition with the desire to retain the [i] of the foreign language source. At level 2, /ti/ succumbs to PAL- $i$ in its function as Retraction and we witness the change $/ \mathrm{ti} / \rightarrow$ [ti] testifying to the completed process of nativization.

\section{Underspecification at intermediate levels: Cracow Voicing}

This section looks at intermediate representations and argues that they also, not only underlying representations, must be permitted to admit underspecification. The issue arises in Derivational OT, not in Standard OT. The latter adheres to the principle of strict parallelism and does not admit intermediate levels and representations between the input (underlying representation) and the output

\footnotetext{
${ }^{20}$ The technical implementation of exceptionality is carried out in terms of co-indexed constraints (see Pater 2006, 2008).

${ }^{21}$ Technically, 'inactive' means that Posteriority and STRID are reranked at level 3 below IDENT $[ \pm$ anter $]$ and IDENT $[ \pm$ strid $]$.
} 
(surface representation). As will be argued below, Cracow Voicing requires intermediate representations and therefore constitutes a problem for Standard OT.

Cracow Voicing (Dejna 1973; Rubach 1996) is a process that voices obstruents before sonorants across word boundaries, but not inside words. It operates in southern and western Poland whose principal city is Cracow (hence the name). The rule covers a broad area. It begins in Poznan in the west of Poland and goes all the way to the southern border with Slovakia.

As just mentioned, Cracow Voicing affects obstruents before sonorants, both consonants and vowels. The process is illustrated in (36), where the word los 'fate' is invariably pronounced with [z], even though it has an underlying //s//, compare los $+y$ [losi] (nom.pl.). The word obraz'picture', on the other hand, has an underlying $/ / \mathrm{z} / /$ because we see $[\mathrm{z}]$ in obraz+y [obrazi] 'pictures'. We would expect the //z// to devoice to [s] before sonorants across word boundaries (Final Devoicing), which is what happens in the central and northern dialects of Polish that I will call Warsaw Polish. The devoicing is not attested in Cracow Polish. We could think of this in the following way: Final Devoicing devoices //z// to /s/ in obraz but Cracow Voicing voices it to [z], like it voices the //s// of los. Such derivational steps are voided in OT by ranking Cracow Voicing higher than Final Devoicing.

(36) a. Cracow Polish

los ojca [loz ojtsa] 'father's fate' los Jana [lozj jana] 'Jan's fate' los Lolka [loz lolka] 'Lolek's fate' los Reny [loz reni] 'Rena's fate' los mamy [loz mami] 'mom's fate'

b. Warsaw Polish los ojca [los ojtsa] 'father's fate' los Jana [los jana] 'Jan's fate' los Lolka [los lolka] 'Lolek's fate' los Reny [los reni] 'Rena's fate' los mamy [los mami] 'mom's fate' obraz ojca [obraz ojtsa] 'father's picture' obraz Jana [obraz' jana]'Jan's picture' obraz Lolka [obraz lolka] 'Lolek's picture' obraz Reny [obraz reni] 'Rena's picture' obraz mamy [obraz mami] 'mom's picture'

obraz ojca [obras ojtsa] 'father's picture' obraz Jana [obras jana]'Jan's picture' obraz Lolka [obras lolka] 'Lolek's 'picture' obraz Reny [obras reni] 'Rena's picture' obraz mamy [obras mami] 'mom's picture'

It might appear that Cracow Polish does not have the process of Final Devoicing, but this is not true, as the following examples show.

(37) Cracow Polish and Warsaw Polish

nom.pl. nom.sg. gloss

obraz+y [obrazi] row + y [rovi] obraz [obras] 'picture' rów [ruf] 'ditch'

Also, Cracow Polish and Warsaw Polish share the rule of Voice Assimilation that voices or devoices obstruents before another obstruent both inside words and across word boundaries. 
(38) Voice Assimilation in Cracow Polish and Warsaw Polish ${ }^{22}$

\begin{tabular}{|c|c|}
\hline licz+y+ć [lijtf] 'count' & $l i c z+b+\mathrm{a}[1 \mathrm{jid} 3+\mathrm{b}]$ 'number' \\
\hline & po $+l i c z$ but $+y[1 \mathrm{jid}+\mathrm{b}]$ 'count the shoes' \\
\hline$\dot{z} a b+\mathrm{a}[3 \mathrm{ab}]{ }^{\mathrm{f}} \mathrm{f}$ & $\begin{array}{l}\dot{z} a b+k+\mathrm{a}[3 \mathrm{ap}+\mathrm{k}] \text { (dimin.) } \\
\dot{z} \mathrm{a} b \text { Karoliny [p k] 'Karolina's frogs' }\end{array}$ \\
\hline
\end{tabular}

Cracow Voicing is expressed as the following markedness constraint.

(39) Cracow Voicing (Cracow Voice)

An obstruent and a following sonorant must agree in voicing.

Descriptively, this presonorant voicing is limited to the configuration obstruent - sonorant across a word boundary. Word-internally, the [ \pm voice] contrast in obstruents is maintained. For example, sosna 'pine tree' has [s], not [z], before a vowel (the first $s$ ) and before a nasal (the second $s$ ): [sosna], which contrasts with los ojca [loz ojtsa] 'father's fate' and los nasz [loz naf] 'our fate.' Since Cracow Voicing applies only across word boundaries, the question is if it is not a derived environment process. Such a restriction would account for the absence of $s \rightarrow z$ in sosn $+a$ while still allowing the voicing in (36a). The answer is negative. Phrases such as los ojca [loz ojtsa] 'father's fate' and los nasz [loz naf] 'our fate' contrast with los + owi [ $\mathrm{s}+\mathrm{o}]$ 'fate' (dat.sg.) and mięs $+n+y$ [s+n] 'meat' (Adj.).

These facts bring us back to the original issue: how to make sure that Cracow Voicing applies only across word boundaries and not inside words. OT's method to limit the application of a process to a subset of contexts is to use positional faithfulness, such as onset faithfulness or root faithfulness. However, neither of these methods works for Cracow Voicing. Root faithfulness is not available because the segment that undergoes Cracow Voicing is in the root, so the application of Cracow Voicing in roots should not be blocked. Onset faithfulness would do a good job for sosna 'pine tree', which is syllabified so.sna so both s's are in onsets and hence would be successfully protected from Cracow Voicing by postulating IDENT $[ \pm$ voice $])_{\text {Onset }}$. However, the presence of the second $s$ in the onset cannot be relied on because Polish shows variation and the syllabification sos.na is not impossible; compare also wieczny 'eternal' and but$n y$ 'arrogant': [vjje.tfni] [vjjkt.ni] and [bu.tni] [but.ni]. If onset faithfulness were to be the way to ensure that Cracow Voicing is blocked word-internally, the variable syllabification should coincide with variable Cracow Voicing. We should therefore see [t] when the syllabification is bu.tny and [d] when the syllabification is but.ny because the former and not the latter would be protected from Cracow Voicing by IDENT $[ \pm$ voice $])_{\text {Onset }}$. However, the facts indicate otherwise. Variation in syllabification does not coincide with variation in Cracow Voicing: sosna, wieczny and butny are pronounced with voiceless obstruents,

${ }^{22}$ For an analysis of Voice Assimilation, see Rubach (1996) and (2008). 
regardless of syllabification. I conclude that exploiting positional faithfulness for the purpose of limiting Cracow Voicing to the context of word boundaries is not the correct hypothesis to pursue.

My proposal is to derive the scope of application of Cracow Voicing from independently existing generalizations. In particular, the idea is to implement the insight originally discovered by Rubach (1996) that Cracow Voicing applies to archiphonemes in the context derived by Final Devoicing. The details of the analysis ensue.

As shown in by the examples in (37), the dialectal area covered by Cracow Voicing exhibits Final Devoicing. The most recent analysis of the voicing facts of Polish is that of Rubach (2008). Rubach's proposal is to derive Final Devoicing from the segment inventory constraint against [+voice] obstruents and positional faithfulness relativized to sonorants.

(40) a. ${ }^{\star}[+$ voice $]$

Don't be $[+$ voice $]$ on an obstruent.

b. IDENT $[ \pm \text { voice }]_{\text {Presonorant }}$

The value of $[ \pm$ voice $]$ on the input obstruent before a sonorant must be preserved on a correspondent of that obstruent in the output.

Being more specific, the positional faithfulness constraint IDENT $[ \pm \text { voice }]_{\text {Presonorant }}$ is by definition ranked higher than the corresponding generic constraint IDENT $[ \pm$ voice $]$.

(41) IDENT [ \pm voice]

The value of $[ \pm$ voice $]$ on the input obstruent must be preserved on a correspondent of that obstruent in the output.

The evaluation of obraz//obraz// is now as follows.

(42) $/ /$ obraz $/ / \rightarrow$ [obras $]$

\begin{tabular}{|c|c|c|c|}
\hline & IDENT $[ \pm \text { voice }]_{\text {Presonorant }}$ & $*[+$ voice $]$ & IDENT $[ \pm$ voice $]$ \\
\hline (a) obraz & & $\star *$ ! & \\
\hline (b) obras & & $\star$ & $\star$ \\
\hline (c) opras & $*$ ! & & $\star \star$ \\
\hline
\end{tabular}

The $[\mathrm{b}]$ in $o b r a z$ is before [r], so before a sonorant, and hence is protected by IDENT $[ \pm \text { voice }]_{\text {Presonorant }}$ This protection does not extend to $[z]$ because $[z]$ is before a word boundary and not before a sonorant. Consequently, [z] falls prey to ${ }^{*}[+$ voice]. The winner is the candidate with Final Devoicing, [obras] (42b), because it violates ${ }^{*}[+$ voice] only once, (due to the [b] being [+voice]) while the competitor without Final Devoicing, [obraz] (42a), violates ${ }^{*}[+$ voice] twice (due to the $[\mathrm{b}]$ and the $[\mathrm{z}]$ being $[+$ voice $]$ ). 
A further candidate, not considered in (42), is [obraZ]. This candidate has obeyed ${ }^{\star}[+$ voice] by deleting the feature [+voice] without replacing it with [-voice], so [Z] is an archiphoneme, underspecified for $[ \pm$ voice $]$. Archiphonemic outputs are eliminated by SPEC (Prince and Smolensky 2004).

(43) SpeC

No underspecified features.

SPEC (Specify) makes sure that outputs are fully specified for all features.

The analysis of Cracow Voicing will fall into place if we make a minimal alteration to Rubach's (1996) analysis and use ${ }^{\star}[ \pm$ voice $]$ rather than ${ }^{\star}[+$ voice $]$ as the constraint deriving Final Devoicing.

$(44) *[ \pm$ voice $]$

No $[ \pm$ voice $]$ on an obstruent.

The evaluation in (42) is now replaced with the one in (45), in which the archiphonemic candidate is the winner. The assumed framework is Derivational OT motivated in Section 2. The relevant level is Level 2 (the word level).

(45) Level 2: /obraz/ $\rightarrow$ /obraZ/

\begin{tabular}{|c|c|c|c|c|c|}
\hline & & IDENT $[ \pm \text { voice }]_{\text {Presonorant }}$ & ${ }^{*}[ \pm$ voice $]$ & IDENT $[ \pm$ voice $]$ & SPEC \\
\hline (a) & obraz & & $* * !$ & & \\
\hline (b) & obras & & $* * !$ & * & \\
\hline (c) & opras & ${ }^{*} !$ & $* *$ & $* *$ & \\
\hline$\infty \quad(\mathrm{d})$ & obraZ & & * & * & * \\
\hline (e) & ॰BraZ & $* !$ & & $* *$ & $* *$ \\
\hline
\end{tabular}

Candidate (45a) violates ${ }^{*}[ \pm$ voice $]$ twice because $[ \pm$ voice $]$ is specified on two obstruents. The same is true for candidates (45b) and (45c). In contrast, candidate ( $45 \mathrm{~d})$ has specified [ \pm voice] on one obstruent (specifically [+voice] occurring on [b]). The other obstruent, [Z], is an archiphoneme, so it is unspecified for $[ \pm$ voice $]$.

The evaluation in (45) is completed at the postlexical level. SPEC is reranked to an undominated position because phonetic outputs must be specified for all features. The archiphoneme /Z/ is spelled out as [s] because [-voice] is the unmarked value for obstruents, a generalization that OT expresses by the ranking ${ }^{\star}[+$ voice $]>{ }^{\star}[$-voice $] .{ }^{23}$

The analysis of Cracow Voicing is now clear. At level 2, all word-final obstruents in the winning candidates lose their specification for [ \pm voice] and become archiphonemes with respect to voicing, an effect of ${ }^{\star}[ \pm$ voice $] \gg$ Spec.

$23 *[+$ voice $]$ and ${ }^{*}[$-voice $]$ say 'don't have the feature [+voice] on an obstruent' and 'don't have the feature [-voice]' on an obstruent', respectively. 
The change affects not only voiced obstruents but also voiceless obstruents, so we have the archiphoneme /Z/ not only in obraz 'picture' but also in los 'fate.' The archiphonemic representations enter Level 4 (the postlexical level), at which Cracow Voicing becomes active and voices both /obraZ ojtsa/ and $/ \mathrm{l} \mathrm{ZZ}$ ojtsa/, deriving the surface representations [obraz ojtsa] and / bz ojtsa], the correct result.

(46) Level 4: /loZ ojtsa/ $\rightarrow$ [loz ojtsa]

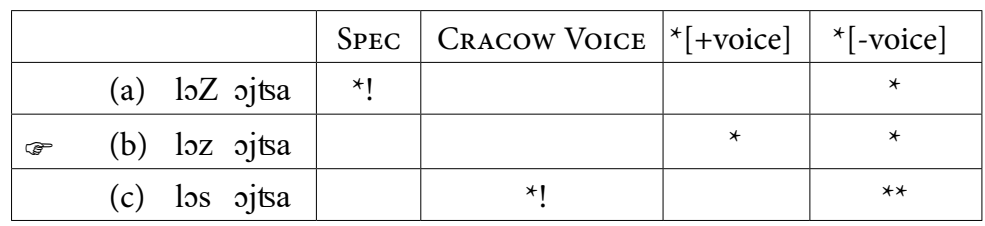

Cracow Voicing does not apply word-medially because word-medial obstruents have not been turned into archiphonemes, as (45) has shown. Word-medial obstruents are therefore specified for [ \pm voice] and hence are immune to Cracow Voicing. This immunity follows from the generic IDENT[ \pm voice] constraint that must be ranked above CRAC VOICE. The interaction is illustrated by kot ojca 'father's cat', in which the second but not the first obstruent undergoes Cracow Voicing.

(47) Level 4: /koD ojtsa/ $\rightarrow$ [kod ojtsa]

\begin{tabular}{|c|c|c|c|c|c|}
\hline & SPEC & IDENT $[ \pm$ voice $]$ & Cracow Voice & ${ }^{*}[+$ voice $]$ & ${ }^{\star}[$-voice $]$ \\
\hline (a) koD ojtsa & $* !$ & & * & & $* *$ \\
\hline (b) kod ojtsa & & & & * & $* *$ \\
\hline (c) kot ojtsa & & & *! & & $x * *$ \\
\hline (d) god ojtsa & & $\star !$ & & $* *$ & * \\
\hline
\end{tabular}

IDENT [ \pm voice] punishes any discrepancy between the value of [ \pm voice] in the input and the output, that is, the value of [ \pm voice] must be preserved in the output. IDENT[ \pm voice] is mute on the final stop in kot 'cat' because it is an archiphoneme unspecified for [ \pm voice], so there is nothing to preserve. That is, the change $D \rightarrow d$ does not violate IDENT[ \pm voice]. The situation is different with the first stop in kot. The $k$ has not undergone Final Devoicing because it is not at the end of the word. Consequently, the $k$ is specified for [ \pm voice] (it is [-voice]). Therefore, the change $k \rightarrow g$ in (47d) is a violation of IDENT [ \pm voice].

To conclude, the analysis proposed in this section makes a direct connection between Final Devoicing and Cracow Voicing. The former prepares the ground for the latter. The prediction of the analysis is that Cracow Voicing is possible only in a language/dialect that has Final Devoicing. This prediction is borne out in Slovak, which has Cracow Voicing and, predictably, Final Devoicing. 


\section{Conclusion}

Static, distribution-based generalizations are accounted for in different ways by Standard OT and Derivational OT. The former uses the principles of the Richness of the Base and Lexicon Optimization, the latter employs underspecification in accordance with the Contextual Predictability Principle. The investigation of three independent processes has shown that underspecification as a method is superior to the Richness of the Base and Lexicon Optimization.

First, underspecification solves the problem of directionality in Nasal Assimilation occurring in the coda, as in camp. It also avoids postulating a multitude of inputs and corresponding evaluations that are necessary in Standard OT under the Richness of the Base.

Second, a study of the assimilation of borrowings into Polish concludes that Lexicon Optimization selects the wrong output as the underlying representation and makes incorrect predictions regarding the direction of nativization. These issues do not occur if the analysis is carried out by assuming underspecification.

Third, underspecification solves the problem of limiting Cracow Voicing to the context across word boundaries. The desired effect is derived from the interaction of Final Devoicing and Cracow Voicing. The analysis requires that representations be archiphonemic (underspecified for [ \pm voice]) at an intermediate level of derivation.

\section{References}

Avanesov Ruben Ivanovich (1968). Russkoye literaturnoye proiznoshenie. Moscow: Prosveshchenie.

Beckman Jill N. (1997). Positional faithfulness, positional neutralisation and Shona vowel harmony. Phonology 14(1), 1-46.

BERMÚDEZ-OTERo Ricardo (1999). Constraint interaction in language change: quantity in English and Germanic. Manchester: University of Manchester, Ph.D. dissertation.

Booij Geert E., Rubach Jerzy (1987). Postcyclic versus postlexical rules in Lexical Phonology. Linguistic Inquiry 18(1), 1-44.

CASALI Roderick (1997). Vowel elision in hiatus contexts: Which vowel goes? Language 73(3), 493-533.

Сhomsky Noam, Halle Morris (1968). The Sound Pattern of English. New York: Harper \& Row.

Clements George N. (1985). The geometry of phonological features. Phonology Yearbook 2, $225-252$.

Dejna Karol (1973). Dialekty polskie. Wrocław: Zakład Narodowy im. Ossolińskich.

HaLle Morris (1992). Phonological features. In International Encyclopedia of Linguistics, William BRIGHT (ed.), 207-212. Oxford: Oxford University Press. 
Jespersen Otto (1904). Lehrbuch der Phonetik. Leipzig und Berlin: B.G. Teubner.

Kiparsky Paul (1982). From Cyclic to Lexical Phonology. In The Structure of Phonological Representations, vol. I, Harry van der Hulst, Norval Smith (eds.), 131-175. Dordrecht: Foris Publications.

KiPARsky Paul (1985). Some consequences of Lexical Phonology. Phonology Yearbook 2, 85-138.

KIPARSKy Paul (1997). LP and OT. Cornell Linguistic Institute: Ithaca, NY, handout.

KIPARSKy Paul (2000). Opacity and cyclicity. The Linguistic Review 17(2-4), 351-365.

LAdefoged Peter (2001). A Course in Phonetics. $4^{\text {th }}$ ed. Fort Worth: Harcourt College.

MCCARthy John J. (1999). Sympathy and phonological opacity. Phonology 16(3), 331399.

McCarthy John J., Prince Alan (1995). Faithfulness and reduplicative identity. In University of Massachusetts Occasional Papers in Linguistics 18, Jill N. BecKMan, Laura Walsh Dickey, Suzanne Urbanczy (eds.), 249-384. Amherst, Massachusetts: Graduate Linguistic Student Association Publications.

Pater Joe (1999). Austronesian nasal substitution and other NC effects. In The Prosody-Morphology Interface, René Kager, Harry van der Hulst, and Wim ZonNEVELD (eds.), 305-343. Cambridge: Cambridge University Press.

PAter Joe (2006). The locus of exceptionality: Morpheme-specific phonology as constraint indexation. In Papers in Optimality Theory III, Leah Bateman, Michael O’Keefe, Ehren Reilly, Adam Werle (eds.), 259-296. Amherst, MA: Graduate Linguistic Student Association.

PAter Joe (2008). Morpheme-specific phonology: Constraint indexation and inconsistency resolution. In Phonological Argumentation: Essays on Evidence and Motivation, Steve PARKer (ed.), 123-154. London: Equinox.

Postal Paul M. (1968). Aspects of Phonological Theory. New York: Harper and Row.

Prince Alan, Smolensky Paul (2004). Optimality Theory: Constraint Interaction in Generative Grammar. Oxford: Blackwell. [Revision of 1993 technical report, Rutgers University Center for Cognitive Sciences. Available on Rutgers Optimality Archive, ROA-537.]

Rubach Jerzy (1984). Cyclic and Lexical Phonology. The Structure of Polish. Dordrecht: Foris Publications.

Rubach Jerzy (1993). The Lexical Phonology of Slovak. Oxford: Oxford University Press.

RuBACH Jerzy (1996). Nonsyllabic analysis of voice assimilation in Polish. Linguistic Inquiry 27(1), 69-110.

Rubach Jerzy (1997a). English syllabification. Anglica 7, 65-84.

Rubach Jerzy (1997b). Extrasyllabic consonants in Polish: Derivational Optimality Theory. In Derivations and Constraints in Phonology, Iggy Roca (ed.), 551-581. Oxford: Oxford University Press.

RuBACH Jerzy (1999). The syllable in phonological analysis. Rivista di Linguistica 11(2), 273-314.

RuBACH Jerzy (2000a). Glide and glottal stop insertion in Slavic languages: A DOT analysis. Linguistic Inquiry 31(2), 271-317.

Rubach Jerzy (2000b). Backness switch in Russian. Phonology 17(1), 39-64. 
Rubach Jerzy (2003a). Duke-of-York derivations in Polish. Linguistic Inquiry 34(4), 601-629.

Rubach Jerzy (2003b). Polish palatalization in Derivational Optimality Theory. Lingua 113(3), 197-237.

Rubach Jerzy (2008). Prevocalic faithfulness. Phonology 25(3), 433-468.

RubAch Jerzy (2011). Syllabic repairs in Macedonian. Lingua 121(2), 237-268.

Rubach Jerzy (2017). Derivational meanders of High Vowel Palatalization. Lingua 199, 1-26.

Rydzewski Paweł (2017). Unwarranted exceptionality: The case of Polish y. Lingua 189-190, 75-95.

SAGEY Elizabeth (1986). The representation of features and relations in non-linear phonology. Cambridge, MA: MIT, Ph.D. dissertation.

SELKirk Elizabeth (1982). The syllable. In The Structure of Phonological Representations, vol. II, Harry van der Hulst, Norval SMITH (eds.), 337-384. Dordrecht: Foris Publications.

SŁAWsKi Franciszek (1952). Słownik etymologiczny. Kraków: Towarzystwo Miłośników Języka Polskiego.

Struijke Caro (2000). Existential faithfulness: A study of reduplicative TETU, feature movement, and dissimilation. University of Maryland: College Park, MD, Ph.D. dissertation.

Trubetzkoy Nicolai S. (1939). Grundzüge der Phonologie. Travaux du Circle Linguistique de Prague 7. [English translation: Principles of Phonology. Berkeley and Los Angeles: University of California Press, 1969.]

Wierzchowska Bożena (1963). Budowa akustyczna a artykulacja dźwięków mowy. Biuletyn Polskiego Towarzystwa Językoznawczego 22, 3-23.

Wierzchowska Bożena (1971). Wymowa polska. Warszawa: Państwowe Zakłady Wydawnictw Szkolnych.

Jerzy Rubach

Department of Linguistics

University of Iowa

Iowa City, IA 52242

USA

jerzy-rubach(at)uiowa.edu

\&

Instytut Anglistyki

Uniwersytet Warszawski

ul. Hoża 69

00-681 Warszawa

Poland

jerzy.rubach(at)uw.edu.pl 